\title{
THE CIVIL WAR LETTERS \\ OF AN IOWA FAMILY
}

\author{
Edited with an Introduction \\ by Richard N. Ellis \\ Asst. Professor of History \\ University of New Mexico
}

War directly affected numerous families during the 1860 s, bringing personal tragedy to many, and the trials and tribulations of the Simeon Stevens family of Oskaloosa, Iowa must have been rather typical. Their story can be seen in the following selection of letters written by various members of the family. They are letters which reveal a truly human story. They demonstrate strong feelings such as love and fear. Above all, they describe the tragedies which befell them. They are somewhat unusual and useful because they are not devoted to descriptions of battles and campaigns. The attitudes expressed here are of greater value to the social and intellectual historian than to the military historian.

The Stevens family contributed more than its share to the Union effort in the Civil War. Motivated by the desire to preserve the Union rather than to free the slaves, Benjamin Stevens, the eldest son, enlisted in the 15th Iowa Volunteers in 1861 with the understanding that his father would remain at home. Benjamin Stevens served in the Mississippi Valley, fighting at Shiloh, serving on guard duty in the TennesseeMississippi region, and participating in the Vicksburg campaign.

Following the surrender of Vicksburg on July 4, 1863, Benjamin Stevens parted company with his comrades in the 15th Iowa and became a member of one of a series of new regiments which were forming. For a young man who had gone to war to restore the Union rather than to free the slaves the change was considerable, for the new regiment, the 10th Louisiana Infantry, African Descent, was black. Efforts to. enlist Negroes in the Union Army had begun at an early date, but it was only after the Emancipation Proclamation that 
major steps were taken in this direction. The new Negro regiments fought with distinction during the Vicksburg campaign, and their performance at Port Hudson was remarkable by any standards.

The black 10th Louisiana, which became the 48th United States Colored Infantry in March 1864, served at Vicksburg and in Louisiana and then fought in Alabama and Florida before returning to Louisiana and Texas. The regiment was mustered out in January 1866.

Benjamin Stevens served throughout the Civil War without harm, but the family had more than its share of suffering. Much to the disappointment of the young soldier, his father broke their agreement and volunteered for service. Benjamin was concerned that his father, Simeon Stevens, was too old to withstand the rigors of soldiering and feared for his safety. These fears proved all too accurate. Simeon Stevens found himself in southwestern Missouri in the vicinity of Springfield; there he soon became ill and was transferred to a hospital in St. Louis where he died.

Following the death of his father, the second son, Stephen Stevens, wanted more than ever to enter the army despite the advice and protests from his elder brother. Benjamin Stevens had sought to provide his younger brother with advice and guidance in the past, encouraging him to continue in school, and after their father enlisted, to manage the family affairs and watch over their mother and little sister, Lillace. When Stephen insisted upon enlisting, his brother brought him into his own regiment. Stephen soon marched eastward with the 15th Iowa and was captured during the Atlanta campaign in the summer of 1864 . The news of his capture was followed by the final tragedy, the death of little Lillace.

The letters of the Stevens family provide an insight into the personal affairs of a Midwestern family which was directly touched by the Civil War. They also include descriptions of life in the army and valuable comments on the southern reaction to the use of Negro troops by the Union Army.

I would like to thank Mrs. A. L. Townsend of Portland, Ore., for making these letters available to me and for donating them to the Iowa State Historical Museum. 


\section{THE LETTERS}

Camp Halleck, Keokuk

Nov. the 27th, 1861

\section{Dear Father:}

I imbrace this opportunity to pen you a few lines, to let you know how things are going here and how the millitary is prospering. We left Keokuk on the 11th and moved out to Camp Rankin.' It consist of twelve houses, each large enough to hold one hundred men and [they] are built out of pine and after the fashion of Rail Road shanties. When we got into quarters, we drew all of our cooking utensils, queensware, axes, hatchets, spades, etc. I was then ordered to take charge of the cooking for the company. I did so and gave satisfaction to all, having 5 assistans. I did not have mutch to do but to manage the affair and see that every man got his rations after they were cooked. We draw rations at present for 82 men. Of bread we draw 114 lbs., being $22 \mathrm{oz}$. to the man. Of coffee $8 \mathrm{lbs}$., Of sugar $8 \mathrm{lbs}$., Of beans or rice 6 quarts. Of beef 113 lbs. to each man or salt Pork ${ }_{3}^{\prime \prime} \mathrm{lb}$. Of Potatoes for company $80 \mathrm{lbs}$. every two days. Of Candles $1 \mathrm{lb}$., Of Soap $3 \mathrm{lbs}$., Of salt and vinegar as mutch as we want. Of Molasses $3 \mathrm{qts}$. once a week. These things we draw once a day at 9 O'clock A.M. We drew our first rations on the 11th of November and since that time we have saved and sold to the amount of seven dollars and 40 cents worth and with the money we buy butter, molasses and sutch things we want. On the 18 th we received orders to move back to town and go into quarters in a large Store Room which we gladly done, for our quarters were begining to get cold. Our quarters are three stories high. We cook and eat on the first floor, sleep on the second, and drill on the third. There are seven other companies quartered in the same building besides ours, and two more are expected by next week, which will fill the Regiment. Some of the companies are not yet full, but will be filled in the course of a

${ }^{1}$ Some changes have been made to modernize the punctuation; original spelling and grammatical construction have been retained. 
week or two. All of the companies have received there uniforms-that is one suit a peace. We expect our Over Coats and the rest of our Blankets in a few days. I was temporarily appointed Second Sergeant when we first came to Keokuk and have filled that place ever since with the exception of the time that I was cooking, which was a week. As soon as our company is full and organised the appointments will be permanintly made, and I have the assrance if I attend to my business, as I have done since I have bin in the Company, that I shall keep the place. Keep this to your self as some thing might turn up that would keep me from getting the perminent appointment. We only lack 1 man of haveing 83 men and as soon as we get him, we will organise, and the Officers will get there Commissions. We have the promise of three men this week, and I think we will get them with out fail. We have as good a set of Officers and men as I would wish to be with. The Regimental Officers are making every exertion in their power to fill up the Regiment so that we can go to St. Louis before the River freezes up, and we will go as soon as it is full ... Father, I want you to keep your promise and stay at home. I am purfectly satisfied here, but if you should leave and go to the army there would be no body to take care of the family, and to leave them in that fix I could not be satisfied.

Ben F. Stevens to the Family

Camp Benton, St. Louis, Mo., March 25th, 1862

Dear Friends:

I imbrace this opportunity to write you annother letter, although James Says that it is not just for us to do all the writing. ${ }^{2}$ It has been about six weeks since we have had a letter from you, although this is the third time we have written. We are well at present and have bin since we last wrote you. We would like to hear from some of you at least every two weeks, and I know it could be done if the thing was rightly

2James, who is mentioned throughout these letters, is James E. Hetherington, a cousin, who was also in the 15th Iowa and who was later elected sheriff of Mahaska County, Iowa. 
managed, so try and do not give us cause to write in this manner again. On the morning of the 19th, we were up by four O'Clock, and by ten O'Clock we were ready to March.Our Knapsacks all packed, three days rations cooked and boxed up. At two P.M. the Jeannie Deans steamed up and made fast. She is a good Boat, well built, medium size and belongs to the St. Louis and Keokuk Packet Company. Orders were then given to shoulder Knapsacks and fall in rank, which was promptly obeyed in the midst of a drenching rain. We were then marched down to the boat and commenced embarking which took about one hour. During the embarkation, hundreds and hundreds of men, women and children crowded the wharf to witness our departure. Many were the "good byes" and "God bless you" that were said to us as we went plungeing through the mud to the Boat. It would be impossible for me to describe the cheering or our feelings as the Boat left the shore. The Band was on [the] harrican [hurricane] deck playing Dixey's-Land (quick-time), while a thousand and fifty men swung their hats and cheered at the top of their voices, and twice that number responded in the same manner on the shore. Our good feeling soon wore off, and by dark we were just on the other extream: we were all crowded on [the] boiler deck, excepting the commissioned officers. They took cabin passage. We were so badly crowded that one half of the boys had to stand up. I tell you now, it was disagreeable. There was a cold wind from the north west, with a drizzling rain. Many of the boys were wet and cold and had to go without their suppers, but they stood up to it without a murmur. As soon as dark came a bout five hundred of us went down in the hold to sleep, and a sweet time of it we had. We piled down on boxes, bales, and barrels with our blankets around us and our knapsacks for pillows, but sleep was out of the question. The boys that stayed on deck piled in around the boilers and pipes to keep warm, and between knapping and hollowing [hollering] we worried the night away. Next morning we took a lunch of cold pork and bread. By this time Alton was past, and twenty miles more brought us to St. Louis. ${ }^{3}$

${ }^{3}$ Alton is a river town on the Illinois side of the Mississippi River above St. Louis. 
The boat turned into the wharf and made fast and at half past nine we marched of on [off of] the boat and formed in line. The Colonel then took command and marched us through the mud and rain about five miles to Camp Benton where we are, at this present time. ${ }^{4}$ Camp Benton is Fremont's hobby. It is the place whare he expended so much money. It consists of an inclosure of about four hundred acres and level as the floor. The fence is about eight feet high and boarded up barn fashion. The quarters are very comfortable and well arranged and will accommodate ten thousand men. There are at present in and around camp, ten Regiments of Infantry and Cavalry and five Batterys. Regiments are. coming in and going out every day. Five Regiments have bin paid off and three armed and equipped since we came. Yesterday our Regiment received their arms and equipage. They are the Springfield rifle, range five hundred yards and are well finished. To day the teams were fited out, each company receiving six good mules and a heavy wagon. The Quarter Master is in possession of the tents and more clothing, and will probably ishue them tomorrow. We will be ready for marching this week. Our destination is not yet known. The supposition is that we will go to New Mexico, but this is unfounded. Gen. Halleck says that Tennessee is the place for Iowa Boys, and there is not doubt but what we will go their. ${ }^{5}$ The Sixteenth Iowa Vol. came in yesterday, and received their arms today. They are all good looking boys, but we have the name of being the best looking Regiment that ever came into Camp Benton.

Col. Rheid [Reid] told our Captain today that we would leave here inside of eight days and he thought we would get our poy before we left; if so, we will express our money home. ${ }^{6}$ The weather has bin very fine since we have been here, and we are putting in the time well. We drill about six hours per

${ }^{4}$ Camp Benton or Benton Barracks was located at St. Louis. It was later used to house prisoners of war.

${ }^{5}$ Henry W. Halleck commanded the Department of the West, and in 1862 he was named commander in chief of the Union forces.

${ }^{6} \mathrm{Col}$. Hugh T. Reid of Keokuk was colonel of the 15th Iowa Infantry. He was promoted to Brigadier General of the Volunteers in 1863. 
day. It would do you good to be here a day or two and see the machin[e] in full blast. You could see three or four thousand men on drill at once, composed of Infantry, Cavalry and Artillery.

I believe there is nothing more of importance at present, only that we want you to write soon and give us all [the] news. Send us some Postage Stamps for fear we do not get our pay, because if we do not get it, no telling when we will get it. We will write as often as the nature of the case requires and keep you posted.

Direct as follows, and if we leave here the letters will follow us.

Ben. F. Stevens, Company D, 15th Reg., Iowa Vol. Camp Benton, St. Louis, Mo.

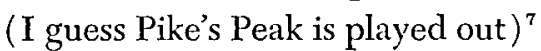

Yours Respt., Beny and James to you all

Dear Friends:

Pittsburgh Landing, Tenn. April 13th, 1862

It is with pleasure that we write to you again. We left St. Louis April 1st in company with five'other Regiments and three Batteries. Our regiment embarked on the Minihaha. We came down the river to cairo, from Cairo up the Ohio to Padeucha [Paducah], and from thence up the Tennessee river to Pitsburgh [Pittsburg] Landing, eight miles above Savanah [Savannah], whare we are at present. $^{8}$ On the 4 th, James took sick on the boat with the lung fever. He was in bed all day a saturday an[d] sunday, as long as I staid with him. About sun up we first heard the roar of Cannon. The

7The "Peak" is undoubtedly Pikes Peak or the Colorado region which he and his father had planned to visit.

${ }^{8}$ Cairo, Ill. is near the junction of the Ohio and Mississippi Rivers. Paducah is about 50 miles above Cairo on the Kentucky side of the Ohio River. Savannah, Tenn., 9 miles north of Pittsburg Landing, was Gen. Ulysses S. Grant's headquarters when the Battle of Shiloh began. Grant had just suffered a painful fall from his horse and was resting at Savannah, but he rushed to the front when the fighting began. 
enemy made the attact when Gen. Grant did not expect them and got the advantage which they kept untill night. At eight we was ordered of [f] the boat and at nine we started for the field of battle and by ten we were engaged in the conflict, which was terable; words cannot express the scen[e]. The enamy drove us back two miles to the landing whare we made a desperate stand and repulsed the enimy. By this time it was dark, and the fireing ceased. From daylight untill dark there was one continual volly of musketry and roaring of Canons. Two Gun Boats played on the enimy all day and all the night following. About five in the evening, Gen. Buel [Buell] appeared with his grand division on the opposite shore and immediatly commensed crossing over to reinforce us. ${ }^{\circ}$ As fast as they landed they were formed in line of battle and marched to the field. A sunday night we laid on the ground on our arms with out anything to eat or wit[h] out our blankets and the rain poured down in torrents. At daylight Buel began the action, and the result was we thrashed them. The line of battle was between six and ten miles long. We lost out of our Regiment, killed, wounded, and missing, about two hundred men. The Battle was harder on monday than sunday and lasted untill dark. I cannot write any thing satisfactory; if I did, it would take a quire of paper and more time than I can command. Old soldiers say that this was the hardest battle that was ever fought in America. Troops are comeing in here all the time, and as soon as the wether settles we expect to move south. Read the papers and you will know more than if $\mathrm{I}$ was to write all the time. James went to Savannah a sunday evening and staid their at the Hospital until Thursday. He was then sent back to camp and was mutch better. $\mathrm{He}$ is at present able for duty. Charles Fowler was killed. I feel that the bullet is not moulded that will kill me.

We are in good health and in good spirits. We haven't got our pay yet and do not know when we will get it. James was not in the Battle. On sunday I was in the midst of a continual shower of shot and shell, but when we was ordered to fall back I must confess that I felt weak in the knees. I thought

${ }^{\circ}$ Don Carlos Buell arrived in time to help turn the tide of battle for the Union. He later commanded the Army of the Ohio. 
we would all be taken, but on monday I had no such thoughts for we drove them from the word go and we can do it all the while...

Beny.

Corinth, Miss., June 15th, 1862

Dear Friends:

...We received our pay on the 4th. James got fifty two dollars and I, Sixty eight. I suppose that you have received money from us before this time, for we started it on the 8th by our Chaplain, Mr. Esterbrook. He was going to Keokuk on busness, and from their he was to express it to aunt and you. James sends forty dollars to his mother, and I send fifty to you. James says for aunt to use his money for the family and herself and for no other purpose. As we received four months pay you may think that we have kept out more than was nicessary, but I tell you if a fellow was to get sick here and is without money, he is in a bad fix. Therefore, I thought it prudent to keep some for our selves. We are at present camped one mile South of Corinth. ${ }^{10}$ I was in their last week. It is almost deserted, only a few families remaning. There was about fifteen hundred soldiers at work, some were building cars and repairing the track and others were repairing the three Locamotives that were in the fire when the Depots were burned down. They will be in running order in a week or two. The bridges are being repaired on the different roads leading from Corinth that was burned down. The cars will be running to Memphis in a week or two. The rebels destroyed thousands of dollars worth of supples before they left. Tents, wagons, Provisions and the camp equipage were all burned. Every thing is quiet here at this time. The rebels that occupied this place are supposed to be at Richmond. Father wrote to know about crops here. Well, as a jeneral thing, there are none; as far as I can hear or see, there is not more than one acre in ten that is planted; the rest is idle. There will not be enough raised in this vacinety to support the inhabits [inhabitants]. Their are nothing raised this season that I have saw but wheat

${ }^{10}$ After the Battle of Shiloh, Gen. Halleck advanced slowly and cautiously toward Corinth, a railroad center about 20 miles to the south. The Confederates evacuated the town in late May 1862. 
and corn. The wheat has bin harvested but the corn looks poor ... J James and I are enjoying the very best of health (but we take good care of ourselves you may depend). This climate agrees with us better than the northern. Either of us will weigh more than we ever did in our lives. How long we will stay here I cannot tell, but when we do go I will give you the particulars. Write as soon as you get this and let us know wether you have received our money yet (if you have not written before you get this); send us some stamps for we have to pay ten cents a piece for them here and can't get them for that half of the time at that price. Write soon as you get this and oblige. Yours,

(Give this to Father)

James E. Hetherington

B. F. Stevens

Dear Friends:

In Corinth, July 2nd, 1862

We received a letter from you to day dated June the 24th, which we were glad to receive and hasten to reply. We were very much relieved to hear that our money had gone safe. But I was some-what surprised to hear that father had Volunteered after he told me he would stay at home if I went, but for all that, I have bin expecting to hear of it ever since the last call for volunteers. I am a little disappointed too, for it has been my calculation to go to the Peak as soon as I get home, and I told him so two or three times. My plan was for him to stay at home and shape everything in such a manner as the nature of the case required and I would send my wages home to help to do it. But if he has bin mustered into the service, we will have to wait til we get out and then fix to go. And I will now say what I think about the matter (that is, to Father if he is yet at home and has not taken the oath, but if he has, you need not send this to him). If you can get out of it honorably, do it, for as far as my experiance goes, you are too old to stand it well, and besides it is the wrong season of the year and you haven't got the right kind of a disposition for a soldier, and as far as going to Washington is concerned, don't put any dependance in that, for it is just 
as likely that you will be sent to Mosoura [Missouri] to guard rail road bridges as to be sent their. Now, don't think I am finding fault or am trying to influence you, for I am not. If you think it is your duty to go, go with all your heart, and all will be right in the end. I feel proud that we have so great a Republic to sustain and that we are able to help do it. Mother, I will say in conclusion, if Father has gone, I want you to write as soon as you get this and give the full particulars and give me his post Office address and I will write him a long letter and give him my experience and observations in soldiering which will be of great value to him. Our Regiment has bin detached from the Division and is in Corinth as a provost guard. We may be here all summer, I can't tell. We have connection with the north by rail road. If our army is successful at Richmond, I think we will be home by fall. Tell me if it was the three year service that father went into. Stephen, I will say to you that much depends on you now, and you must begin to think; you have the care of little Lill and Mother and with this great care, dear brother, be a man, stay at home and care for them, do what your Mother tells you. Don't let them want for any thing that you can do. And when I get home, you shall go with me to the Peak, and if we make any thing I will share it with you. I will write once a week to you. Nextime I will write you a long letter and tell you all a bout the Prisnors we have here and a great many things. Don't forget my advice...

B. F. Stevens

Camp near Bolivar, [Tenn.], August 13th, 1862.

\section{Dear Brother:}

I take my pen in hand to write you a letter according to promise. I received your kind letter of the 3 rd yesterday and was glad to hear that you were all well. You say that Lill has bin having the ague. Now you must take good care of her and have her well as soon as posable. James and I are in excilent health and good spirits. In one of my letters I promised to give you a history of Soldier's life and the duties he has to perform. I hardly know where to begin, he has so much to do. Well, I will begin in the morning. As soon as it 
is grey dawn, the Drummers and Fifers get up and play the revalee. Then the Orderly Sergeant of each company gets up to wake their respective companies. The Orderly then calls the roll to see that all the men are present. Every man is duty bound to be at roll-call. As soon as roll-call is over the Orderly takes a list of all the sick that is in camp and takes them to the Doctor. All of those that are not able for duty are put off duty for that day. As soon as the Surgeon's call is over, then comes the Orderly's call. He then reports to the Ajutant the number of men in camp for duty, the number sick in camp and hospitals, the number of Teamsters, Cooks, and those on detached duty and Officers. In fact the OrderlySergeant has to make a report every morning, and account for every man that belongs to the company, present and absent. As soon as this report is over, then comes the Battallion drill which lasts one hour. That over, then comes breakfast. Breakfast over, then comes the details. There are from four to eight men detailed to stand Guard. Guard is mounted at eight O'clock and stands untill eight next morning when it is relieved. The guard stands on post two hours and off four. From two to four men are detailed daily for Fatigue duty and from two to four for police duty, and besides this there are generally from three to four detailed to go with the teams for Forage or Beef or Rations. All details are made by the Orderly. As soon as the details are made and sent off, then the camps are policed by the men that are in camp-that are not on duty. Each tent is carefully swept and the ground in front. The dirt is hauled of [f]. Every thing is kept very clean. Holes are dug in the ground by each Cook's fire and all the scraps, off falls, [and] dish-water is put in to them and covered up eacch morning. All of this work is done before ten O'clock. From ten O'clock untill four, all that are not on detail duty have nothing to do but attend to their own affairs. In camp all is regularity. Whare companies are small the men come on duty about every other day. At four O'clock is company drill and at six, Dress Parade. At eight tattoo is played and the Roll is called, and at quarter past eight taps is beat and all the lights are put out. All this duty comes daily. 
I can say without boasting that we have the best company in the Regiment. It is composed principally of young farmers from the vacinity of Ottumwa, all possessing good morals, with few exceptions. We have bin complamented more than once by our Colonel and Brigadier General for our good behaviour in camp and on marches and for the neat appearance of our camp, and in the army no complaments are given unless they are deserved. We are at present about two miles from Bolivar on detached duty with Company $\mathrm{H}$. of the 13th Iowa and about two miles from the Regiment. ${ }^{11}$ Our duty is to guard a Rail Road Bridge. How long we will be on this duty, I cannot tell at this time. There are about six hundred Negros at work on the fortifications at this place. They have all been pressed into the service by the Military authorities. They get their cloths and board and something beside but I do not know how much. We are haveing all the green corn, peaches, apples, and fresh meet that we want to eat. When any thing of this kind is wanted, all we have to do is to get our team and send eight or ten [men] with it as guards, and send them in to [the] country and they bring it in. I will close for the present but will continue in my next letter. Write to me often.

B. F. Stevens to Stephen Stevens

Springfield, Mo. Sept. 15th. 1862

Dear Wife:

I rec'd your letter of the 6th inst. yesterday. . . I am obliged for your kindness in sending those stamps as they are hard to get here. I am sorry to hear of your being sick \& disconsolate. Well, you must keep your spirits up and receive all news for the best. Now don't worry and grieve for my absence as I am doing very well, in good health, spirits, \& God grant the same to you. You must pray that not only for me to come home in full health \& strength but that I may discharge all the duties incumbant on me with fidelity \& honor to my country \& friends, as the greatest calamity would be, I consider, to

${ }^{11}$ Bolivar is near the Hatchie River in southwest Tennessee between Shiloh and Memphis. 
bequeath the name of a coward to my family \& children, which by the blessing of God I never will, but borrow no trouble for me. I am fully recovered of our hard journey \& can say with the testimony of my comrades that I stood it better than many younger persons in the regiment. We moved our camp from the Sauk [Sac] river to one half mile west of Springfield, being the identical ground that Gen. Ben McCullough [McCulloch] camped on last year. ${ }^{12}$ This place is full of reminiscences of this war as the graves of Secesh \& union men is to be seen all around us, they being killed in the charge made on this very ground by Gen. Fremont's body guard. Many houses are burnt down, farms destroyed in the vacinity of this town. The fame of this town is greater than the town. It is not so large as Oskaloosa yet it is a considerable inland town \& is the main depot for the stores of the army of the West of the river. In a meeting yesterday held by the Chaplain, Our Colonel at the close rose \& said he has reliable news that the rebels were marching upon us in two solid columns near 30,000 strong, \& our forces, 10,000 men, were retreating. They were within two days march. Our men are fighting as best they may \& retreating to give us a chance to prepare for them \& to day we have a very heavy force throwing up breast works to be continued day and night. Our general has called in every man within from 3 to 5 miles to come and work in the fortifications, closed all stores in town \& ordered everybody, white and black, to be set to work, \& every hour we hear and see men coming in giving ... some account of fighting all around us. Among them, I believe, is Jim Lane ${ }^{13}$ of Kansas \& this morning we could hear quite distinctly the report of guns \& cannons in camp in the direction of the old battle ground of Wilson Creek. Our general has called for all the available reinforcements from different places to come in \& assist in Keeping this post. We are in a

${ }^{12}$ Brig. Gen. Benjamin McCulloch, formerly a captain in the Texas Rangers, had participated in the Battle of Wilson's Creek in Missouri. He was killed at the Battle of Pea Ridge in Arkansas in March 1862.

${ }^{13} \mathrm{Jim}$ Lane had fought in the Mexican War and had been active in Indiana politics before moving to Kansas. He was a hero of the Kansas Free Soilers, a U. S. Senator and commanded some of the Kansas troops in that state during the war. 
brigade of the 37 th Illinois \& 25 th Indiana besides there is a very large body of cannon unknown to me, several cavalry regiments \& six thousand looked for to night, making in all about 20,000 men. We have no fears of the result $\&$ are determined to make this \& hold it as our base of future operations against Fort Smith \& Arkansas. I think the rebels only intend to scour the country for supplies, yet he would, if he could, take this post. We are receiving better fare than we did at Sedalia. We get good soft baker's bread \& fresh beef occasionally but $I$ have not seen a good hill of potatoes or cabbage since I left Iowa, yet fruit is plenty \& good \& cheap. We bought 3 pecks of peaches in camp for $1 \frac{12}{2}$ pints of coffee this morning. Every thing is dear in this place. Cotton yarn is $\$ 4$ a bunch, corn, when sold, about 30 cts a bushel. Yet this is good farming country in this vicinity, yet the havoc of war is great. I was surprised you said nothing of Benjamin, of course you heard nothing of him lately. I see by the papers the rebels are moving about where he was lately, yet I trust in God all may be well.

Yours in all the bonds of affection,

Simeon Stevens

October 12th, 1862

My verry dear Husband:

I received your kind letter of the 28th of Sept. . .I believe I have recieved all the letters you have Sent to me. I have received three since you left Sedalia up to October the 8th. I am looking for one now from you. I haven't heard from you Since the battle. No one knows what Suspense a Soldier's wife Suffers, only them that has the trial. With that trial I have a dear Son whose life I have to trimble for, but the good lord has preserved his life thus far. Wee are all well at presant and doing as well as eny body could do among sutch a Set of people ... Now, dear, do let me [know] how it is with you as soon as you can after a battle, and if you should git wounded do not keep it from mee. . This is October the 11th, Saturday night; the clock is striking nine; the children is in bed a Sleep while I rite these lines. Now, dear, do not let the dutyes you 
owe to your God bee neglected. Remember they are more binding then military dutyes. Remember your in an enemay land and if you Should bee So unfortunate as to bee taken prisner turn that time to good account and Spend your time reading and praying and doing all the good you can. Do not let the hard scenes of war demoralise you in eny way, but keep your eye on the path of duty. O, my dear Simeon, if you $[\mathrm{k}]$ now the anixiety I feel both for your spiritual and temperal wellfare, it wood stimulate you to duty. Live faithful to every known duty. Lillace is cracking walnuts. I ask[ed] her what I must rite for her. She said tell pap and Benny I am picking walnut goodys out for them. . . Remember, my daily prair is for your best interst. . .

From your affectionate wife. rite soon.

Mrs. Elizabeth Stevens

St. Louis, [Mo.]

Jan. 4th, 1863

Dear Madam:

I have just returned from visiting the Hospital where I met your husband, Simeon Stevens, who arrived last night with a number of others from Rolla. He is as comfortably situated as could be expected away from home, having a good Doctor, with kind and attentive nurses. His room is large, well ventilated and [has] a comfortable bed. He expects soon to get a discharge and will then be at home with you all once more. $\mathrm{He}$ is very anxious to hear from you and wants you to write just as soon as you receive this and let him know the news ...

I remain yours, Henry Glover ${ }^{14}$ A visitor to the hospital

${ }^{14}$ Henry Glover cannot be accurately identified. He may have been a member of the U. S. Sanitary Commission or one of the other volunteer groups which served as a civilian auxiliary to the medical bureau in tending the wounded. 
Camp 15th Iowa, Lafayette, Tenn., Jan. 8th, 1863 Dear Mother and Brother:

...From Abbeville we moved south in connection with Grant's whole force. ${ }^{15}$ When our forces had got as far south as Coffeeville, Gen. Vandorn [Van Dorn] made a raid around to the rear of Grant's army, destroying all the army stores and supplies that was at Holly Springs, besides destroying all the Rail Road bridges in that vacinety. There was several raids made at the same time on the Rail Road between Cornith and Columbus. ${ }^{10}$ These raids have been some what disastrous to Grant's army. When the Rail Road was torn up our supplies was cut off and we have had to retreat without a general engagement. Not exactly retreat, but had to fall back whare we could get supplies. We are now on the Memphis and Charleston Rail Road, thirty miles from Memphis. We have not had any mail at all from the 15th of Dec. to the 5th of Jan. We had three days mail burned at Holly Springs when Vandorn took that place. I was beginning to get somewhat uneasy to hear from you and Steve. I have not had a letter from Father yet, only those that you sent. I wish that he would try and write to me. You say that you are looking for him at home. This I am glad to hear for I always knew that he could not stand the service. You ask my advice in refferance to going after him. This is a hard question for one to answer. If you should go and he has not got his discharge, he could not go home with you at all, for no man can get a leave of absence from the army. If he should get his discharge and is able to travail [travel], he can come home by Rail Road by the way of St. Louis, Mo., for he will have to come that way to get his pay. It has been so long since you wrote that I cannot give you any positive advice. But I will tell you if he has not yet got home, you had better write to him immediately and have him answer it. If he has his discharge, and is not able to come by him self, I would go after him: but you had better know these things before you start: In

${ }^{15}$ Abbeville, Miss. is a few miles north of Oxford. Coffeeville is in Yalobusha County, Miss. and is northeast of Granada.

${ }^{16}$ Gen. Earl Van Dorn evacuated Holly Springs, 36 miles southeast of Memphis, in the face of superior Union forces. In December 1862, in an effort to disrupt Grant's supply lines, he attacked Holly Springs. 
case you go, I want you to take as much money as will pay your expenses their and back. I feel very anxious to hear from him and know all about his disease. You must write same as soon as this comes to hand. . .

Stephen, I am glad to hear from you and know that you are going to school. Atend as regular as you possable can and try to improve your time to the best advantage. The Pay Master is expected here tomorrow. We will get pay in a few days without doubt. I do not think we will draw the full amount due us. We have it reported here to day that Gen. Sherman is fighting at Vicksburg and Gen. Rosecrans is fighting Brag [Bragg] at Murfreeboro, Ky. ${ }^{17}$ Each one has 70,000 men, so reports say. They had been fighting two days with out decisive results. It is expected that Rosecrans will [be] succussful. James and I are in good health.

Ben F. Stevens to you all Send us some stamps.

St. Louis, [Mo.]

Jan. 23rd, 186.3

Mrs. Elizabeth Stevens

Dear Madam:

Little did I think when I wrote a day or two ago, that it would soon be my painful duty to announce to you the sad news of your Husband's death, but such is life. At a moment when we least expect, our loved ones leave us for that blessed home above where we are all tending.

When I read your letter his face brightened up and [he] said his mind felt relieved to know that you were all well, and That morning felt stronger and was anxiously looking forward to the day when he would be with you all again, but the hope did not last long, for the next day he began to grow worse and so continued until the next morning (Thursday) between 5 \& 6 o'clock when he was relieved from all sorrow and suffering, having finished the work given him to do here on earth

${ }^{17}$ Gen. William T. Sherman moved against Vicksburg late in December. Gen. S. Rosecrans fought Gen. Braxton Bragg to a draw at Murfreesboro, Tenn. on Dec. 31, 1862, and eventually occupied the town. 
and is now joining his voice with the angels in giving praise to God.

Let it be a lesson to us to be always ready so when the summons come we will be prepared as I really think he was, for in all conversation his thoughts were of his family and his God.

After he died the body was washed, then dressed in a clean white shirt, drawers and stockings and after several hours, placed in a neat wooden coffin and buried in a burying ground expressly for soldiers. A board with his initials marks the spot where the loved one rests. An accurate account is kept of each grave so at any time the friends are visiting they can find the spot without difficulty. . Your husband left some clothing and should you want it, you will please send as soon as possible a power of attorney authorizing me to get the clothing and send it to you ... Your husband's discharge was being made out but did not reach him before he died.

Hoping that our Heavenly Father will give you strength to support you in your hour of sorrow, and with my heartfelt sympathy for you and your bereaved family, I remain your friend,

Henry Glover

A visitor to the hospital

Dear Mother and Brother:

Fifteenth Iowa, Jan. 24th, 1863

I write these few lines to let you know how things are going at this time. Our Division embarked on the 18th and on the 20th, our fleet left Memphis for Vicksburg. We have landed on the Louisiana side at Mulligan's Bend [Milliken's Bend], some fifteen miles from Vicksburg. Our trip has been every thing but a pleasant one, for we have been crowded on board of the Minnehaha with the 16th Iowa, but we are through safe and sound ...

I have some bad news to tell you of: that I have heard, but I cannot believe it untill I hear from you. We passed Halena [Helena] on the 22nd and stoped their about one hour: while we stoped their I was a sleep; but James told me that he 
saw some boys of the 33rd and the 36th Iowa. He says that he saw a fellow by the name of Morgan, but did not know whether it was John Morgan or not, who told him that he had heard Father was dead. He told James that one of the Boyd boys belonged to his regiment and he had got the news in a letter from home, but Morgan could not tell James the date of the letter. Now, we received a letter from Aunt dated Jan. 13th. We got it on the 19th which was six days a coming. I know that was later news than they could of got at Halena because there was no boats passed Memphis while we was their. So I think there is a mistake about the report somewhare. At least I cannot believe it untill I hear from you. Aunt's letter states that he was at St. Louis and was getting better-that he had good care and attention and a good place to stay at.

I cannot give you much information at present about our operations here. We have a large army here. It is the intention of our Generals to work it so that we will not have a fight at Vicksburg. By looking on the map you will see that there is a large bend in the river on the Mississippi side and Vicksburg is about the middle of the bend on the same side of [the] river. Now our army is digging a canall across this bend so as to turn the channell of the river away from Vicksburg. If this can be accomplished, it will not be necessary to take this place, for the river will be open for navegation. Every thing is favorable, the river is rising fast. All believe the canall will be a successful operation ...

Write soon, as I am anxious to hear from you. I will write again in a few days to let you know how things are going from here.

Ben F. Stevens O.S. Co. D.

St. Louis, [Mo.], March 12th, 1863

\section{Mrs. Stevens}

Dear Madam:

Your letter was received several weeks ago and [I] am sorry that it has remained so long unanswered but hope you will excuse me when I state that since your letter came to hand, my time has been more occupied than ever, some nights 
writing till one and two oclock. . Every thing was done for his [Mr. Stevens] comfort. His nurse both by day and night were very kind and attentive, and beside the men nurse there is one lady to each floor whose duty it is to cook small delicasies and they act towards them as a Mother. When they are not able to go to the general table, their meals are brought to them. For breakfast \& supper, cold bread or toasted with tea or thickened milk to drink, and butter or preserves to spread on their bread; for dinner, vigetables \& meat suitable for their sickness, what ever it may be. The beds are well provided with covering which is changed once a week.

I called to see your husband the day before his death. I read and prayed with him; I asked him if he had anything particular [to say]; he said nothing ... That day he was able to be up and walked to the end of the room, but the same night he had congestion and was taken off ... The clothing was sent by Express about the 26th of last month, and has no doubt reached its destination long before this ... I remain with much sympathy, your friend,

Henry Glover, Jr. a visitor to the Hospital

One more word which I forgot. He wanted me to write That he was continually thinking of you-and to his children he hoped they would be good children and mind whatever their Mother tells them to do...

Dear Mother:

Camp 10th La. Vols. of A.D. Goodriches Landing, La., August 12th, 1863

I take this opportunity to write you a few lines in return for your kind letter which I recieved some days ago dated July 13, 1863. I also received at the same time one from Cousin Anna, and one from Stephen. The reason that I have not written sooner is that I have been away from the Regiment on Recruiting Service. I was fifteen miles in the rear of Vicksburg when I received the leters. I started on recruiting service on the 23rd of July with a detachment of my Company. We went aboard of a boat to Vicksburg and from their we 
took the cars to Black River, some fifteen miles from the city. I stayed untill the 8th of August and in the mean time I recruited one hundred thirty-three good men, which filled up our Regiment to the required number. There are a great many Regiments organising in this Department at this time. The work is progressing beyond description. Old father Thomas, the Adjutant General, has again made his appearance down here. ${ }^{18}$ His mission is (so reports stay) to organise and equip more Colored Troops and to look after Nigger[s] generally. But as to this the papers will keep you fully posted. But the thing is demonstrated, the nigger will fight. It has been proved whare ever they have had a chance, but these things you know. I have talked with numbers of Parolled Prisoners in Vicksburg and they all admit it was the hardest stroke that there cause has received-the arming of the negrow. Not a few of them told me that they would rather fight two Regiments of White Soldiers than one of Niggers. Rebel Citizens fear them more than they would fear Indians. They say their doom has come and nothing but death and destruction awaits them. These things I see and hear almost daily. We are using their own strength against them. I am well satisfied and can work with a good heart and I tell you the work is progressing fast. In six months there will be seventy five thousand colored troops put in to the field, armed and equiped. Since the negrow troops have come in to the field the guirilla warfare is fast playing out. But here let me state that I have changed my mind but very little in Reference to the Abolition question-you know my mind. I would rather see our country as it once was than as it now is. The Rebellion is about once through in this department. A great many citizens in the vacinity of Vicksburg have taken the oath of allegiance and are returning to there homes. I was in Vicksburg some two or three days, and I tell you it is one of the most desolate places that I ever saw. The city is built on a

${ }^{18}$ Old Father Thomas is Lorenzo Thomas, Adjutant General of the U. S. Army. He was dispatched to the Mississippi Valley in March 1863 to recruit as many Negro regiments as possible. 
stack of hills. The hills are full of caves and tunnels dug by the Rebs during the siege to protect them from the Shells... If nothing happens I will be at home this fall to see you all and I tell you I want Stephen to stay at home untill I come up and he shall come down here with me. I have the promise and the chances are good to come. Tell Stephen for me not to think of going in to the Service unless he goes with me. If I do not come home, I will send for him as soon as it gets cool weather. If he should go into a Regiment by him self the chances are against him. I have had some experiance and have watched these things close and what I speak I know. If he will stay home untill he comes with me I will pay him the amount per month I promised him last summer. Do not let him go into another Regiment if you can help it . . .

In times like these we should be very liberal in our views. We must expect to meet and mingle with a great many persons that have diferent ideas from ours. I tell you if you could see as much trouble, suffering, and misery as I have seen in the south, your heart would bleed for this unfortunate people. You must not think that I sympathize with the Rebal cause, for I do not. I feel more like helping to put down the Rebellion than ever. I think in less than six months the war will be over. I would to God it was over now. I. saw citizens around Vicksburg that did not have a ful dinner for six months before our army gave it to them. Let me tell you, it is a hard sight to see a woman with five or six small children come to a commissary and beg for hard bread. These things are of a daily occurance. They all will tell you that they have not had an ounce of salt in the house for twelve months-what our soldiers did not take from them, the darkeys did. It is the women and children that suffers here ... When you write don't forget to give me the gossip. Tell me all that happens and give my best regards to all my friends. Yours in haste, Yours most obediently,

Ben. F. Stevens 
Head Quarters 48th USCI

Dear Mother:

\section{Vicksburg, Miss., Aug. 14th, 1864}

I have just received very sad news from - Atlanta and I expect ere this reaches its destination you will have read the same news. Stephen is reported among the missing. To day I received two letters from James-one dated July the 24th and the other July 29th. The first was written after the close of the three day fight, ending on the 22nd, and the other was written after the battle of the 28th. He was in a great hurry at each writing and could not give me full details but from what he writes, I take it that Stephen was with them the lst and 2nd day and was not missed until after the battle of the 22nd. James writes that just as the rebels drove our men away from their works, he saw Stephen coming away and at that time was unhurt. He mentions the names of some fourteen others belonging to Company " $D$ " that are missing. In his letter of the 29th none of the missing had been heard from. He thinks there is no doubt but what they were all taken prisoners. After the battle was over our men were sent out to burry the dead and none of the missing were found among them. Now, this is good evidence that he is not among the killed as each detail passes over the ground that its regiment went over.

Yet, it is verry, verry sad for us to know that he is gone, and it may be that he is gone to return no more. We must prepare for the worst and meet it if it comes, but something tells me that we will all see Stephen again. I do not know whether it is a fancy or a presentment, we will put our trust in him that doeth all things and hope for the best. . .

Your affectionate Son, B. F. Stevens

Dear Mother:

Head Quarters 48th USCI Vicksburg, Miss., September 9th, 1864

I have just received your kind letter of August 24th. It is strange that it was so long on the way. This is the third or fourth letter that I have written to you since you wrote to me of the disappearance of Stephen. I have had many letters 
from Company " $D$," 15th Iowa since the battle of the 22nd and they all agree in stating that to the best of their opinion and belief, Stephen is a prisoner of War. But so far nothing has been heard from him or any of the missing. If he is a prisoner I think we will hear from him soon, as there will certainly an exchange be made soon. I feel greatly in hopes that we will see him again.

The first of this month, I made an application for leave of absence. It was approved at Brigade and Division Hd. Qrs., and $I$ have every reason to believe that it will be approved at Gen. Sherman's Hd. Qrs. and at the War Department as it was very strongly endorsed. If it returns approved I think I can stay at home a full twenty days. I look for it about the 1st or 5th of next month. Well, Mother, as far as resigning is concerned - I will tell you - I feel that my country needs my services for at least six months. She will then be out of danger. Now is the turning point. Every man that feels that he is accountable to a just God for the deeds done in the body should give himself as a willing sacrifice to his country in this, her hour of need. I would never live in America if our cause is not successful, Therefore I cannot go home and look on with indifference. I would not be worthy of the sympathy and protection that the culprit gets. If the draft is a success in the north, or in other words, if Grant and Sherman are furnished with the men that the President has called for, this war will end before nine months. But if the Copperheads and Peace men succeed in carrying out their principals, we will have war as long as there is a single square foot of land in the North that dare call itself a free soil. Think of this and then thank God that you have children that will support the Government that your Father supported. . .If our country's affairs take a favorable turn soon, why then, I will come home to stay but I don't look for that much before next Spring. We have begun to build winter quarters in Vicksburg. Ours are to be large and roomy and will be comfortable. The paymaster will be here by the 12th inst. I do not know whether I will send any money home before I come or not - unless you think you will need some. In case you do, let me know and I will send you some. . Write soon, Affectionately yours, Ben F. Stevens. 
Dear Mother:

HdQrs. 48th USCI

Vicksburg, Miss., Oct. 28th, 1864

Yours of 16th inst is at hand announcing the sorrowful news of the death of dear little Lillace. She has only gone before us a short distance. When our time comes may we be as well prepared to go as she was. It is hard, very hard to part with her but we know she is better off than any of us. She has left a world of sin and sorrow, trials and troubles for one of endless happiness and pleasure. Why should we mourn and be unhappy. We must strive to meet her in that house where she lives. I had hoped to see her here on earth once more, but I always felt as though I never would. I cannot tell what impressed the idea on my mind.

...As soon as we are paid I will start for home. I have my leave. You need not write until you hear from me again. I am well. Your affectionate son,

B. F. Stevens

\title{
THE HOOVER-WALLACE CONTROVERSY DURING WORLD WAR I
}

\author{
by Donald L. Winters \\ Asst. Professor of American History \\ University of Northern lowa, Cedar Falls
}

In many respects, World War I was a difficult and trying time for Americans. Not only was the country involved in its first war abroad, but there were accompanying problems, tensions, and disagreements on the homefront. One such disagreement gave rise to a bitter conflict between an Iowan, Henry Cantwell Wallace, and a former Iowan, Herbert Clark Hoover. The controversy disrupted activities connected with the war effort and was to have repercussions later when both men were members of the cabinets of Warren G. Harding and Calvin Coolidge in the early 1920s.

Hoover, the son of a blacksmith and small dealer in agricultural machinery, was born in West Branch, Iowa, in 1874. Both parents, who were devout Quakers, died before 
Copyright of Annals of Iowa is the property of State of Iowa, by \& through the State Historical Society of Iowa and its content may not be copied or emailed to multiple sites or posted to a listserv without the copyright holder's express written permission. However, users may print, download, or email articles for individual use. 